\title{
Inflammation, senescence and cancer: interweaving microRNA, inflammatory cytokines and p53 networks
}

\author{
Curtis C Harris
}

\author{
From 16th International Charles Heidelberger Symposium on Cancer Research \\ Coimbra, Portugal. 26-28 September 2010
}

The p53 pathway is an intrinsic monitor and response pathway of telomeric attrition involved in cellular aging and senescence. Cellular senescence is tumor suppressive that can be activated by p53 in cancer cells. We are studying the molecular mechanisms of cellular senescence in normal and malignant human cells and the role of the telometric multiprotein complex, shelterin, that includes TRF2 and POT1 [1-3]. Our ongoing studies have revealed that $\mathrm{p} 53$ and its endogenous isoforms regulate both specific microRNAs and TRF2 expression as mechanisms of replicative senescence. In addition, POT1 isoforms are functionally diverse in both maintaining telomeric integrity and preventing p53dependent senescence induced by telomeric shortening. A switch in the expression patterns of p53 isoforms, $\Delta 133 \mathrm{~Np} 53$ and p53 beta, is also associated with the transition of benign to malignant human cancers.

Chronic inflammation and deregulation of microRNAs have roles in human carcinogenesis [4-7]. In addition to our mechanistic and genetic studies, we are investigating the expression of microRNAs and inflammatory genes as cancer biomarkers of diagnosis, prognosis, and therapeutic outcome [8-11]. We are especially interested in developing prognostic classifiers of early stage cancer.

Published: 24 September 2010

\section{References}

1. Fujita K, Mondal AM, Horikawa I, Nguyen GH, Kumamoto K, Sohn JJ, Bowman ED, Mathe EA, Schetter AJ, Pine SR, Ji H, Vojtesek B, Bourdon JC, Lane DP, Harris CC: p53 isoforms Delta133p53 and p53beta are endogenous regulators of replicative cellular senescence. Nat Cell Biol 2009, 11:1135-1142.

Correspondence: curtis_harris@nih.gov

Laboratory of Human Carcinogenesis, NCl, Bethesda, MD, USA
2. Yang $\mathrm{Q}$, Zheng $\mathrm{YL}$, Harris CC: POT1 and TRF2 cooperate to maintain telomeric integrity. Mol Cell Biol 2005, 25:1070-1080.

3. Yang $Q$, Zhang R, Horikawa I, Fujita K, Afshar Y, Kokko A, Laiho $P$, Aaltonen LA, Harris CC: Functional diversity of human protection of telomeres 1 isoforms in telomere protection and cellular senescence. Cancer Res 2007, 67:11677-11686.

4. Hussain SP, Hofseth $\sqcup$, Harris CC: Radical causes of cancer. Nat Rev Cancer 2003, 3:276-285

5. Tlsty TD, Coussens LM: Tumor stroma and regulation of cancer development. Annu Rev Pathol 2006, 1:119-150.

6. Croce CM: Causes and consequences of microRNA dysregulation in cancer. Nat Rev Genet 2009, 10:704-714.

7. Schetter AJ, Heegaard NH, Harris CC: Inflammation and cancer: interweaving microRNA, free radical, cytokine and p53 pathways. Carcinogenesis 2010, 31:37-49.

8. Schetter AJ, Leung SY, Sohn JJ, Zanetti KA, Bowman ED, Yanaihara N, Yuen ST, Chan TL, Kwong DL, Au GK, Liu CG, Calin GA, Croce CM, Harris CC: MicroRNA expression profiles associated with prognosis and therapeutic outcome in colon adenocarcinoma. JAMA 2008, 299:425-436.

9. Schetter AJ, Nguyen GH, Bowman ED, Mathé EA, Yuen ST, Hawkes JE, Croce CM, Leung SY, Harris CC: Association of inflammation-related and microRNA gene expression with cancer-specific mortality of colon adenocarcinoma. Clin Cancer Res 2009, 15:5878-5887.

10. Seike M, Goto A, Okano T, Bowman ED, Schetter AJ, Horikawa I, Mathe EA, Jen J, Yang P, Sugimura H, Gemma A, Kudoh S, Croce CM, Harris CC: MiR-21 is an EGFR-regulated anti-apoptotic factor in lung cancer in never-smokers. Proc Natl Acad Sci U S A 2009, 106:12085-12090.

11. Yanaihara N, Caplen N, Bowman E, Seike M, Kumamoto K, Yi M, Stephens RM, Okamoto A, Yokota J, Tanaka T, Calin GA, Liu CG, Croce CM, Harris CC: Unique microRNA molecular profiles in lung cancer diagnosis and prognosis. Cancer Cell 2006, 9:189-198.

doi:10.1038/ncb1928

Cite this article as: Harris: Inflammation, senescence and cancer: interweaving microRNA, inflammatory cytokines and p53 networks. BMC Proceedings 2010 4(Suppl 2):O1. 